on May 8, a "severe" one, lasting 3 seconds, took place at Plevje, in Bosnia (p. 84). From Dr. Johnston-Lavis we further learn that Vesuvius was in a state of active eruption during the end of April and the beginning of May (p. 34), but no relation is suggested even in this case, and it is quite evident that the facts do not serve to prove the connection assumed.

I do not wish to assert that in no case are synchronous earth. quakes related, for we have undoubted evidence that certain shocks have been very widesprad from a single centre (as the great Lisbon earthquake in 1755 ) ; but it is my belief that nearly every earthquake, whether large or small, is due to strictly local stratigraphical causes, quite irrespective of volcanic agency. Having made many fruit'ess attempts myself to co-ordinate different well-authenticated shocks, I have been compelled to disbelieve the theory of their general connection, and have now adduced sufficient evidence to show that the verdict pronounced by Dr. von Reheur-Paschwitz, that "we may therefore safely conclude that the disturbances noticed in Germany were really due to the volcanic action which caused the earthquakes of Tokio," is not proven, and fallacious.

4 Mecklenburgh Square, W.C.

William Wiite.

\section{The Sources of Nitrogen in Vegetation.}

THE discrepancy between the results obtained in the experiments on plants grown in free air instead of closed vessels appears to be general, as stated in NATURE (p. 3.33). Some years ayo I ventured to suggest an explanation of this, based on an observation made in the course of some investigations of atmospheric dust particles,

Sheets of paper, smeared with adhesive coatings, and shallow vessels of water, were laid on the ground in a garden near willesden. The resulting catch included far more organic than inorganic matter, the organic matter consisting chiefly of smal insects. The amount of these was surprisingly great towards the end of summer or reginning of autumn, quite sufficient, I think, to account for the varying results obtained by Sir J. B. Lawes and Prof. J. FI. Gilbert, especially for the "eccentric" behaviour of the Leguminose-" sometimes the plants died of nitrogen hunger; sometimes, after a ime of sucl hunger, they recovered and produced ahundant growth." The explanation may be confirmed or refuted by exposing an unplanted layer of sterilized sand, or otber soil, of the same area as that on which the experimental plants are growing, and comparing the gain of combined nitrogen in both cases. W. MatTIEU Writiams.

The Grange, Ncasden, August 16.

\section{Do Cats Count?}

AFTER reading all the accounts of the interesting experiments lately performed on the famous "Sally," I am persuaded the following incident may not be without a certain interest to some readers of NATURE.

About two weeks ago, the cat of a dairyman in this neigh. bourhood gave birth to three kittens. Next day, one of them was removed, during the mother's absence, and drowned. On returning from a foraging expedition, and discovering her loss, puss immediately set out in search, presumably, of the missing one. All her efforts in this direction, of course, proved fruitless ; but, evidently determined to at least make up the right number, she did so, curionsly enough, by carrying off, from its nest close by, a young hare, not more than a week old. This she is at present suckling side by side with her own kittens. In view of these facts the above question very naturally suggests itself.

Winchburgh, N.B., August 15 .

J. T. WALKER.

\section{Anapophyses.}

MY attention has been called to a statement by Prof. Cope (NATURE, July 25, p. 298), that anapophyses are "wanting from the vertebræ of anthropoid apes and man." He probably means that they are very feebly developed, which is true. I have found them, however, to exist distinctly in Troglodyles and Simia from the eleventh dorsal to the second lumbar vertebra, and in Hylobates from the tenth to the fifteenth trunk vertebra, and sometimes beginning as high up as the third dorsal vertebra.

Hurstcote, Chilworth, August I2.
The International Chemical Congress-A Correction.

A MISPRINT has occurred in the notation adopted by the Chemical Congress for phenanthrene. The Secretary of the Nomenclature Section has also informed me that a slight modification has been made on the minutes, with regard to acridine, to make the notation adopted correspond more closely to that of the other "multi-ring" compounds. The two formulæ should be-
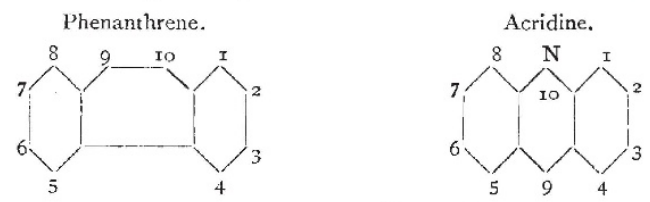

Your CorRespondentr.

\section{THE FRENCH ASSOCIATION FOR THE ADVANCEMENT OF SCIENCE.}

THE eighteenth meeting of the French Association for the Advancement of Science opened under the happiest auspices. The magnificent Exhibition on the Champ de Mars and the Esplanade des Invalides, which has attracted to Paris an exceptionally large number of foreign men of science, is in itself the most conclusive proof of French energy and the progress of French science during the last decade. It is, perhaps, as M. de Lacaze Duthiers remarked, a more effective declaration of a sincere desire for peace than the utterances of certain diplomatists. But there is no place for politics in the principles of the French Association. Foreigners of all nations have been welcomed to Paris not only with warm-hearted hospitality, but with an artistic splendour of which they may well be envious for their own countries, and to which we shall allude later.

We may mention the presence of Messrs. J. H. Gladstone, F.R.S , R. McLachlan, F.R.S., Catalan, Candèze, Istrati, Berlinerblau, Orloff, Stephanos, Van Beneden, General Wauwermans, MM. Szabo, Valdemar Schmidt, Alexeieff, Bierens de Haan, Coleman, Colley, Franchimont, William Watson, Egoroff, Joukovsky, R. de Luna, A. Macfarlane, Ragona, ThomasWilson, Benedikt, Hugo Gyldèn, Packard, Retzius, de Selys-Longchamps, Angström, Brusina, Flavitzky, Graebe, Dufour, Timiriazeff, von Goldschmidt.

The first meeting took place on Thursday, August 8, in the large hall of the Palais des Sociétés Savantes, which has just been erected by private enterprise in the quaint little rue Serpente which now affords a home to so many of the learned Societies of Paris.

The President of the Association for the year is the well-known Professor of Zoology at the Sorbonne, M. de Lacaze Duthiers, who chose as the subject of his inaugural address, "The Development of Zoological Method."

M. de Lacaze Duthiers began his address by thanking the Municipality of Paris for their invitation and for their generous subvention of $£ \mathrm{I} 200$ recently voted towards the year's expenses. He then made a touching allusion to the foundation of the Association.

"It was one day in July I87 I, that Wurtz, whose geniality and whose kindly vivacity you have not forgotten, took me, in his friendly way, by the arm, and said to me as we left the Academy of Sciences, "Come to my house to-morrow night; I want to speak to some of our colleagues of a plan which I much wish to succeed.' On the Tuesday we met at M. Wurtz's house, just a few friends, MM. Delaunay, Claude Bernard, Decaisne, and myself. One may say that this was the first meeting of the French Association.

"As the only survivor of those who were our masters and our friends, I could not forbear from speaking to you of the intimate conversation in which our Association originated. I still seem to see and hear Wurtz with his kindling enthusiasm, with an activity at times feverish, but always 
good-hearted, striding across his drawing-room and giving us a picture of what our Society should, according to his idea, be- of what it has since become." 1

$M$. de Lacaze Duthiers then proceeded to describe the state of zoology a hundred years ago.

"When I789 came, Linnæus and Buffon had just died, and their fame was at its greatest splendour. They were the absolute masters of zoology, and the whole science was summed up in their work. Yet how different were the two in their nature and their work.

"Linnæus, precise, methodical, a classifier above all, introduced clearness and order into the most minute details of natural history, and as he proposed a nomenclature at once simple and precise his influence acquired such a preponderance that von Haller complained of his tyranny. If the reform of scientific language proposed by Linnæus took such immediate and powerful hold on the scientific world, it was because it exactly corresponded to the need of the moment.

"Before Linnæus, the objects of natural history were designated by the help of names or phrases formed by the addition of adjectives describing their characteristics, which overburdened the memory. All this he reduced to two words, just as in our families we distinguish the various members by a family name and a Christian name. The simplicity, the ease of application, and above all the opportune appearance of his nomenclature were the causes of its great success ; but we must add that its intrinsic value is such that even to-day we hardly depart from the rules on which it is founded.

"The opposite of Linnæus, Buffon delighted in broad delineations, and his general reflections were animated by a potent inspiration. We are carried away and enthralled by the profundity of his thought, the elevated standpoint from which he views science. By reasoning and the consequences of observations which he interprets, he seeks as much to discover what will take place, and what must have taken place, as to determine the exact nature of what he observes. And thus he was often in advance of his epoch, and his Iofty views could be understood only by the few.

"Linnæus, on the contrary, established facts with simplicity and clearness.

"With qualities such as these, these two men of genius, who died towards the end of the last century, must often have been at variance; and though the name had not yet been pronounced, we may already at this epoch distinguish between the school of facts and the school of theories (l'école des faits et l'école du raisonnement).

"But there was wanting to the works of Linnæus and Buffon a foundation whose necessity made itself imperatively and universally felt. For it was beginning to be perceived that the study of the habits, of the geographical origin, and of the external characters of animals was not sufficient.

"Then came Cuvier. It was the great merit of Cuvier to see clearly that if zoologists would arrive at a truer knowledge of animals, they must not content themselves with a description of their external forms, but must investigate their internal construction. It was thus that he introduced the notion of anatomy into natural history."

M. de Lacaze Duthiers proceeded to defend Cuvier's memory from unjust attacks which it had suffered owing to his opposition to Lamarck.

"Let us not judge great men by their weaknesses. By wishing to depreciate them, we often arrive at a contrary result, and lessen ourselves by a display of systematic and unjustifiable hostility. Let us see in them only what is

${ }^{x}$ It need hardly be said that Wurtz founded the French Association on the model of our British Association. From the war of 1870 dates a remarkable renaissance in French scient: fic activity, which had been in abe $y$ ance during the Empire, or at least till M. Duruy came into power in 1869 as M.nister of Public Instruction, and founded that unique institution for the encouragement of research, the École des Hautes Étules. good and great. And then we shall not fail to recognize the fact that Cuvier is entitled to our fullest meed of admiration."

The lecturer continued by pointing out that Geoffroy St. Hilaire and Lamarck occupied the same position with regard to Cuvier that Buffon had held with regard to Linnæus. Their speculations were too advanced, they came before their time.

"Zoology remained stationary for many years after Cuvier, and it was not before the beginning of the century that new ideas sprang up directing research along fresh paths, and profoundly modifying certain branches of biological science.

"It is strange to see how books and observations of considerable value often remain obscure for years, and are then finally brought to light by some unespected discovery.

"I remember that about the year 1855 Prof. Huxley, the illustrious English savant, wrote to me (I was then Professor at Lille): "In England we are all much excited about the discoveries of M. Boucher de Perthes.' You. all remember the interest aroused by the discovery of the chipped silexes of St. Acheul, and the famous jaw of Moulin Quignon.

"English geologists came to Amiens. The most lively discussions took place, and an International Committee was formed to direct an official excavation.

"But perhaps the real discovery made, and this was due chiefly to the journey of the English saz'ants, was that of the books, the researches, and the new ideas of Boucher de Perthes, which had hitherto passed almost unnoticed.

"We may say that from this moment dates the study of prehistoric times, which has undergone so immense a development. The excitement produced by the discoveries of M. Boucher de Perthes had begun to calm down, and researches were being pursued in every direction, when the first of Darwin's essays appeared in $185^{\circ}$ and 1859 . These dates will remain for ever memorable in the history of natural science, for henceforward zoology (the only science of which I am at present speaking) takes an entirely new direction.

"We must acknowledge that whatever the measure of confidence we have in the theory of transformism, if we admit it to its full extent, with all its consequences, or if we reject it, it can be a matter of doubt to no one that this theory has led to a truly extraordinary scientific activity. Partisans and detractors both--in seeking for proofs of their opinions, either in the mysteries of embryology or in the investigation of the animal remains in geological strata-all, whatever their method, their ideas, their opinions, or their hostility, have caused zoology to take great strides.

"How far removed we are from the time of Linnæus, when external characteristics were everything-from the time of Cuvier, when anatomical notions and the study of exterior forms alone guided the classifier !

"To-day, what we seek for first of all is the enchainment of animals, either by going back to the forms of the past from those of the present, or the converse. We seek to explain the varied forms we see by the laws so happily formulated by Darwin-laws, indeed, which are as true as they are seductive.

"Who can deny the struggle for existence? Is it not to be found everywhere? And who will not admire the effects of selection? But why exaggerate its true bearings?

"Evolution is to be met with everywhere, in the civilized world as in the world of Nature, development is the great and eternal problem, resolved by the destruction of some, by the advancement of others; everywhere the struggle for life shows itself, inflexible and fatal.

"One may be a partisan or not of the theory of evolution -and I have not here to declare my own opinions, but rather to determine the exact influence of certain dis. 
coveries and certain men on the progress of science-but one is forced to bow to facts, and to acknowledge the magnitude of the prodigious impulse given to science by the great English naturalist. But, as Claparède would say, there are enfants terribles of evolution-men more anxious to be spoken of than to discover the truth.

"We must carefully distinguish them from the conscientious men of science who investigate precise facts patiently, scrupulously, and laboriously, to deduce from them consequences in support of their theory. Men such as these make science advance surely, whereas the others sometimes compromise the cause.

"The only thing to oppose to exaggeration, the influence of excessive enthusiasm, is recourse to experiment. Today, that is the great reform which we feel to be as necessary as those other reforms of whose history I have spoken."

Before developing this idea, the lecturer spoke of Lamarck, and of the reason why his ideas were not adopted during his lifetime.

"Of late years people have thought they had rediscovered Lamarck, and have severely blamed the generation of zoologists who neglected for half a century the author of the 'Philosophie Zoologique.'

"It is true that in the works of Lamarck there are whole pages which contain the theory of transformism completely developed, to which Darwin has added nothing, and which we may say he has but confirmed.

"But if Lamarck had not the satisfaction during his lifetime of seeing his ideas admitted, it was that the minds of zoologists were not sufficiently prepared for them; it was that he had not the rare good fortune of finding a precise and lucid formula, whose truth is evident, and which is necessarily accepted by all.

"Some of Lamarck's conceptions of Nature are even difficult to understand, and especially to make clear to others; and I do not see that even his most ardent admirers have insisted on this portion of his work, and yet it is by no means inconsiderable.

"We should have been glad to see it more clearly explained than it is in the original, and brought within the comprehension of all, and one wonders why it should never be referred to.

"For a reformer to succeed, his idea must be striking in brilliancy and precision; it must master us by its intrinsic seduction.

"Take Darwin, showing us the struggle for existence taking place everywhere and at every instant, and leading to the selection and survival of the victor.

"Take Cuvier, who, it was said, reconstructed an extinct animal from a fragment of bone. A statement like this appealed to the imagination of the masses, and he excited the admiration of a whole generation when he compared an organism to an equation of which we may determine the unknown by the known quantities it contains.

"If Lamarck did not have the success he deserved, it was because of the abstract form he gave to his opinions, and the often naive proofs which he adduced in confirmation of his theories at a moment when enthusiasm and popular attention were diverted to another aspect of science.

"Lamarck was, moreover, regarded as a visionary because he believed in the possibility of forecasting the weather from observations of the atmosphere and of the forms of clouds, and yet who would now blame him for his hopes?

"Lamarck was a man of genius who foresaw the advances of science on many sides, but who did not possess the faculty of being able to present his ideas in a felicitous form intelligible to his con. temporaries."

The lecturer then returned to his theme, that experimental research in zoology is the need of the hour, and proceeded to give some striking examples of the results to which it has led.

Firstly, he described the alternation of generations in the gall-producing insect, whose two forms were originally known as Biorhiza and Teras. The Biorhiza, a wingless and asexual form, is born from eggs laid in the roots of the oak; it crawls up to the branches, and there causes the gall excrescence as it lays its unfertilized eggs. From these eggs issue the sexual winged form Teras, which conjugate; and the female then lays her eggs in the roots of the oak, and from these spring the Biorhizæ.

He then spoke of the strange metamorphoses of a certain insect Sitaris, semi-parasitic on a species of bee, Anthophora, which have been investigated by M. J. H. Fabre, and of those of the lobster. In all these cases, forms supposed to have been different have proved to belong to the life-history of one and the same animal.

"It is because zoology is at this moment at a critical period, and because of the positive nature of the affirmations made by the partisans of transformism, that the methods of the science must be modified, and that besides simply registering the existence of species, we must have constant recourse to the test of experiment. Such is the conclusion at which we logically arrive, and which to-day, I repeat, has become imperative.

"I have sought to point out to you the considerable part which our country has played in the progress of the natural history of man and of animals during the century which is drawing to a close.

"I should have wished to spea's also of the origin and development of other branches of biology, of comparative and general anatomy, of experimental physiology, anthropology, and palæontology. But I think I have said enough to show that I am justified in spurning the reproaches and inimical accusations so often made against us, that France is a country in which scientific work is on the decline, and whose decadence is at hand.

"We open our meeting full of joy in the present, of hope for the future, in presence of the imposing spectacle whose success has but increased since it began in May, and which demonstrates the inanity of these accusations. Let your labours, varied $a$; they are important, prove once more, during a year so fertile in pacific manifestations, that we work only for the restoration of our country, and that the peace of which others speak much, and perhaps believe in but little, is the sole preoccupation of all men of sense, of all who are in earnest in this country of FranceFrance whose desire is to remain free and independent, ever animated by the most generous and patriotic of sentiments."

At the conclusion of M. Lacaze Duthiers' speech, which was most enthusiastically cheered, the Treasurer announced that the receipts for the year had been $£ 3760$, the expenses $£ 3480$, and that the total capital of the Association amounted to $f 33,060$. An important legacy of about $£ 7000$ had been bequeathed to the Association by M. Girard, for the promotion of researches on prehistoric man.

The proceedings concluded with a report on last year's meeting at Oran, and the members then adjourned to the École des Ponts et Chaussées, where the Sectional sittings took place.

The French Association is subdivided into seventeen Sections and sub-Sections: (I and 2) Mathematics and Astronomy ; ( 3 and 4 ) Civil and Military Engineering and Navigation; (5) Physics; (6) Chemistry ; (7) Meteorology (8) Geology and Mineralogy ; (9) Botany ; (I0) Zoology, Anatomy, and Physiology; (I I) Anthropology ; (I2) Medical Science ; (13) Agriculture ; (14) Geography ; (15) Political Economy ; (16) Pedagogy; (17) Hygiene.

An immense number of papers were contributed to the 
Sections. We may mention:-(Sections I and 2), M. Joukowski, on an apparatus for determining moments of inertia. (3 and 4) M. Pichou, on a universal paddlewheel ; by altering the direction of the paddles, a steamer may be reversed without reversing the engines, (5) M.M. Baille and Féret, on a method for reading the oscillations of the balance with great precision; the authors employ a very simple optical arrangement, which allows them to estimate the I/200oth part of a milligram by the displacement of a series of Newton's rings. (6) MM. Alexeieff and Werner, on the heat of neutralization of certain aromatic compounds; the authors show that the general results already acquired enable one to determine in certain cases the position of disubstituted compounds. Messrs. Gladstone and Perkin, on the relation between constants of refraction, dispersion, and magnetic rotation in organic compounds. M. Cazeneuve, on camphor derivatives. M. Franchimont, on the action of nitric acid on organic bodies according to their function. M. C. Chabrié, on the synthesis of selenium organic compounds. M. Raoult, on a new form of the apparatus for cryoscopic observations; the author produces cold by the evaporation of carbon disulphide. M. Meunier, on insoluble crystalline compounds of mannite and sorbite, with the aldehydes, serving to isolate these bodies from organic mixtures (the juice of fruit, \&c.). M. Berlinerblau, on a sweet body, $\mathrm{NH}_{2} \cdot \mathrm{CO} \cdot \mathrm{NH} \cdot \mathrm{C}_{6} \mathrm{H}_{4} \cdot \mathrm{OC}_{2} \mathrm{H}_{5}$. M. Istrati, on new general methods for the synthesis of aromatic compounds. (7) M. Crova, on the standardization of actinometers. M. D'Abbadie, on the qobar. M. Angot, on the representation of the variation of temperature by a harmonic formula. (8) M. Szabo, on the opal mines of Hungary. M. Malaise, on the Belgian Olethamias. M. Bleicher, on the glacial formation of the Vosges. (9) M. Timiriazeff, on the rôle of light-intensity in the assimilation of carbon by plants. M. Mer, on variations of structure in the wood of pines. M. Clos, on certain cases of hybridity in plants, and on the vegetation of Marchantia polymorpha. (Io) M. de Lacaze Duthiers, on the fusion of nerves and ganglia in Mollusca, and on the interpretation of the membrane which separates them. M. Beauregard, on the Cetacean ear. M. Packard, on the distribution of the organs of taste in insects. $M$. Sirodot, on the dentition of elephants. M. Jourdain, on the necessity of conjugation for the continued propagation of Protozoa. M. de Varigny, on the action of certain convulsive poisons on Carcinus menas. (II) M. A. Bertillon, on the anthropometric characteristics of the French nation classed by the departments. M. V. Schmidt, on the Stone Age and the prehistoric Iron Age in Denmark. M. de Mortillet, on right- and left-handed individuals in prehistoric times. M. Manouvrier, on anthropometric researches on natives of Algeria. Dr.Maurel, on the relation of the section of the thorax to the height and the length of the foot. (I2) M. Massé, an instrument for determining the position of the fissure of Orlando. M. Steinhaus, on the causes of suppuration. M. Jolly, on the use of iodine in tuberculosis. M. Luys, on the pathological anatomy of madness, and on the action of rotating mirrors on the nervous system. M. Michel, on the influence of drinkingwater on public health. (13) M. Kunckel, on the destruction of locusts in Algeria. M. Ladureau, on a rapid method of colorimetrical analysis for nitrates. M. Deherain, on the loss and gain of nitrogen in arable lands and on the graphic representation of crops. (I4) M. Castonet des Fossés, on the future of the Negro race. M. Gauthiot, on a route for mining exploration from Bangkok to Korat. The Prince of Monaco, on dragging in deep water. M. de Guerne, on an exploration of the Forno de Graciosa (Azores). (I 5) M. Arthur Raffalovich, on economic legislation in England in I888. M. Martineau, on the true motives for the introduction of free trade into England. M. Ch. Grad, on insurance against old age and infirmity in Germany. (16) M. Frederic Passy, on a system of writing which permits blind people to communicate with the non-blind; M. Paul Passy, on spelling reform ; M. Herzen (of Lausanne), on the organization of certain secondary schools to enable them to continue the teaching of the primary schools. M. Morel, on the organization of the enseignement speciral in the secondary schools of Paris. (I7) M. Delthil, on diphtheria and its treatment. M. Teissier, on diphtheria at Lyons. MM. Dubief and Brutel, new experiments on the value of sulphurous acid as a disinfectant.

The work of the Sections was most usefully supplemented by visits to different institutions and to the Exhibition. Sections $\mathrm{I}$ and 2 inspected the collection of calculating machines at the Conservatoire des Arts et Métiers, under the guidance of M. Ed. Lucas. Sections 3 and 4 examined the new steerable balloons with the inventor, Commandant Renard, while various other parts of the exhibition of the Minister of War were explained by officers of the special departments. Section 6 inspected the fine collection of chemical products at the Champ de Mars (Class 45), general explanations being given by MM. de Clermont, Riche, Suilliot, Billault, Istrati, and others. M. Tanret showed his interesting exhibit, including specimens of pelletierine, the alkaloid of the pomegranate bark now so extensively used as a tænifuge, and ergotine, the active principle of ergot of rye, by whose discovery $M$. Tanret has rendered such signal service to therapeutics, and last, but not least, M. Grimaux, Professor at the École Polytechnique, gave an account of the fine exhibition of Lavoisier's papers and instruments, which he had selected from the collection of M. de Chazelles, to whom they belong, ${ }^{1}$ and pointed out the portrait of M. and Mme. Lavoisier, by David, in the Palais des Beaux Arts. Section 7 met at the Exhibition to see the instruments which record the direction and the vertical and horizontal components of the wind on the top of the Eiffel Tower, the results being transmitted electrically to the Palais des Arts Libéraux, and inscribed on M.M. Richard's revolving drums. The Section also met at the Central Meteorological Office to see experiments on cyclones by M. Weyher. Sections 8,9 , and to inspected the fine galleries at the Museum, which have just been opened.

Other scientific visits were paid to the Institut Pasteur, the sewers of Paris, and to various glass-works, gasworks, \&c. On Thursday, August 8, the Municipality of Paris threw open their magnificent suite of rooms at the Hotel de Ville to the members of the French Association; while extraordinary animation was lent to the scene by the presence of the students of Paris and their foreign comrades, 8000 guests in all having been invited. On the following evening, the Association was received by M. Yves Guyot, the Minister of Public Works, and Mme. Guyot at the Ministry in the Boulevard St. Germain. A concert was given during the evening by members of the Opéra Comique; while the gardens lighted up by Chinese lanterns afforded a pleasant change from the crowded salons.

On Sunday, August I I, an excursion was made to St. Germain-en-Laye, and to Meudon, dinner being served in the orangery which belongs to the beautiful grounds of the Astronomical Observatory, directed by M. Janssen. M. Janssen offered a warm welcome to the members, and said that he should be very willing to let his Observatory be used for the scientific purposes of the Association. On Monday, August I2, a lecture was delivered by General Tcheng-Ki-Tong, on the social economy of China. On Wednesday, August I4, the Association offered a banquet to its foreign members at the Restaurant d'Alsace-Lorraine on the first story of the Tour Eiffel.

M. de Lacaze Duthiers made a short speech, in which he declared that he would not say good-bye to the foreign guests, but au revoir, as he hoped to see them all again

$x$ M. Grimaux has published this year a renrarkable monograph on Lavoisier (Félix Alcan). 
at the meeting of the Association next year at Limoges. That they did not forget past events was proved by the name of the restaurant in which they met, but he firmly believed that "Le temps prime la force," and he drank "to the peace of the whole world."

MM. van Beneden, Dekterev, Istrati, Hartog, Ramon de Luna, Llaurado, Stephanos, Timiriazeff, and Watson, spoke in the name of their respective countries, and drank to the cause of peace and to the prosperity of France.

On Friday, August 16, a general excursion took place to the paper works at Essonne, and to the works of $M$. Decauville (the constructors of the narrow-gauge railway in the Exhibition), who offered a lunch to their guests.

Thus concluded this brilliant and successful session of the French Association.

All foreigners must have carried away with them a pleasant memory of their welcome. Special thanks are due to Prof. Gariel, the Secretary of the Association, and to the Vice-Secretary, Dr. Cartaz, for the remarkable kindness and courtesy they showed to the foreign guests.

EXPERIMENTS ON ELECTRO-MAGNETIC

RADIATION, INCLUDING SOME ON THE PHASE OF SECONDARY WAVES

$\mathrm{I}$ continuation of some experiments which were de1 scribed in NATURE, vol. xxxix. p. 391 ("Repetition of Hertz's Experiments and Determination of the Direction of the Vibration of Light") attempts were made to obtain periodic reflection of electric radiation from plates of different thicknesses, analogous to Newton's rings, with the view of further identifying these radiations with "light."

It was there described how a sheet of window-glass refused to reflect the Hertzian waves, but how a masonry wall reflected them readily. The non-reflection from the thin sheet is due to the interference of the reflected waves from each side which takes place owing to a change of phase of half a period on reflection at the second surface, as in the black spot of Newton's rings.

By making the reflecting plate such a thickness that the reflection from the back has to-travel half a wavelength further than that from the front, the two reflections ought to be in accordance, for they differ by a whole period, half arising from difference in path, and half from change of phase on reflection; but if the difference in paths were made a whole wave-length by doubling the thickness of the plate, there ought again to be interference, and so on.

The first plan tried with this end in view, was to fill a large wooden tank to different depths with water or other liquids. On gradually filling the tank reflection should be obtained, and at a certain depth equal to $1 / 4(\lambda \sec r) / \mu$, reach a maximum; further addition of the liquid then should diminish the reflection, and at double the above depth the reflection should reach a minimum, the two waves interfering.

The mirrors for concentrating the radiation had for this purpose to be suspended over the tank as shown in the figure. The tank was first tried empty, but unfortunately the wooden bottom was found to reflect, thus it was useless for the purpose intended. I then tried what ought to have been tried before constructing the tanknamely, whether ordinary boards, such as flooring, reflected. The floor was found to reflect readily. This was attributed to moisture in the wood causing it to conduct, specially as wood was found not to polarize by reflection. Experinsents were then undertaken to determine if water reflected, even though in thin sheets. A large glass window was placed beneath the mirrors and flooded with water; this was found to reflect well, both when the mirrors were in the position shown and when rotated to the position "at right angles." Thus water also acts like a metal, reflecting the radiation however polarized. The glass had to be hardly more than damp in order to get some reflection.

The wooden tank being unsuitable, a glass tank was thought of, but was given up for solid paraffin, which, being in slabs, could be easily built up into a vertical wall of any desired thickness. Through the kindness of Mr. Rathborne a large quantity of this was lent for the purpose.

A thin sheet of paraffin about 2 centimetres thick was found not to reflect, as was expected. Next a wall i 3 centimetres thick (I 80 centimetres long, 120 centimetres high) was tried, and found to reflect, this being the thickness required in order to add another half period to the retardation of the wave reflected from the back at an incident angle of $55^{3}$, the wave-length being taken as 66 centimetres, and the index of refraction being taken as $\mathrm{I} \cdot 5 \mathrm{I}$, the square root of $2 \cdot 29$, the value taken as the specific inductive capacity of paraffin.

Then a wall twice the thickness was tried, but it also reflected, contrary to expectation. While in doubt as to the cause of this, it was decided to make a determination by direct experiment of the index of refraction of paraffin for these waves, by a method suggested in NATURE (vol. xxxix. p. 393), which consists in interposing a sheet or wall of paraffin between the resonator and the metallic reflection in the Hertzian experiment of loops and nodes which are formed by the interference of the reflected wave with the direct radiation; the ratio of the velocity in the wall to that in the air being easily found from the observed shifting of the loops and nodes towards the screen.
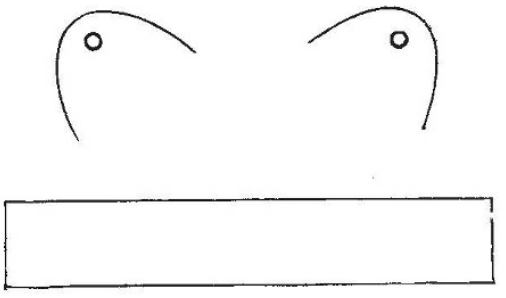

FIG. I.

In this way the index of refraction for the radiation of the period employed was found to be about I.8, so that the paraffin walls which had been used were too thick; The proper thickness being about 10 and 20 centimetres -- exactly so for an incident angle of $5 \mathrm{I}^{\circ}$. On making this alteration I fancied I could detect a slight difference between the reflections from the thick and thinner walls; still the difference was not sufficient to be at all sat isfactory. The nature of the observing apparatus makes it almost impossible to say if the reflection on one occasion is more intense or less so than on another so long as sparks can be obtained. This is due to the sparking-point in the receiving apparatus continually requiring readjustment when working with small sparks, as the distance between them changes either from shaking or from the points getting burnt up. Dust and moisture from the observer's breath are also troublesome. ${ }^{1}$ Thus it might be quite possible that the points had always to be much closer with the 20 centimetre wall than with the Io centimetre wall in order to get sparks, and yet the difference escape detection; the thing observed being whether sparks can be obtained or not, the eye being incapable of comparing with any degree of accuracy the intensity of light on one occasion with that on another.

However, if it had been possible to suddenly change the wall, while viewing the sparking, from being 10 to 20 centimetres, it would have been easy to detect any

I With very small sparks the thermal expansion must be counteracted by unscrewing. 